\title{
蒸気発生器爆着プラグ部の環境強度に関する研究*
}

\author{
加賀精一**, 藤井克弘 $2 * *$ ， 山本義秋****，小川恒一*****，藤岡芳博******
}

Study on the Strength of Explosive Plugged Part in the Environment

of Steam Generator

by Seiichi Kaga**, Katsuhiro Fujii***, Yoshiaki Yamamoto****,

Kouichi Ogawa***** and Yoshihiro Fujioka******

Supposing the case in which leakage takes place in tubing of steam generator, the explcsive plugging method was developed by Japan Welding Engineering Society etc. It was indicated by the researchers that this method is effective to the purpose.

It is not yet known whether the plugged parts keep the stable strength or not, during the long service period in the environment of steam generator.

Under the above consideration, following three tests on plugged part are conducted.

1. Thermal Shock Test

2. Stress Corrosion Cracking Test

3. Liquid Sodium Corrosion Test

Testing results are grained as follows.

1. Peeling occures immediately after beginning of thermal shock test. Cracking occures after $150 \sim 200$ thermal cycles in SH, 200 400 thermal cycles in EV and 1000 thermal cycles in SG.

2. Residual stress in tube plate near the plug is compressive. SCC does not occur in the tube plate there. It occures on the inner surface of plug.

3. The susceptibility to SCC of explosive bonded boundary is lower than that of base metal due to martensite in bonded boundary.

4. Explosive bonded boundary is somewhat weaker than base metal in the resistance to the sodium attack under the testing condition employed in liquid sodium corrosion test.

Key Words: Explosive Plugging, Thermal Shock Test, Stress Corrosion Cracking, Liquid Sodium Corrosion, Steam Generator, Fast Breeder Reactor

1. 緒霄

原子炉の蒸気発生器の伝熱管に洩れが発生した場合を 想定して, 日本溶接協会, 動力炤・核燃料開発事業团, 旭化成工業俶によって爆着プラグ法が開発されだ,2). また爆着プラグ部の機械的強度については, 日本溶接協 会爆着プラグ評価委員会のメンバー2)によって，その㳡 全性が調查された。しかし爆着プラグ部が原子炉蒸気発 生器の中の環境の中で長期に使用された場合の強度の安 定性については未だ検討されていない。

爆着プラグ部の猿境強度は多面的に検討する必要があ る上考えられるが，著者等は次のようなあのを考え，研 究を行った。

1）爆着プラグ部の形状的な特徽から応力集中部が存 在すると考えられる．そこで原子炉運転中のバルプ 類の操作ミスなどによる熱衝撃がかかった場合に対 する特性の研究が必要である。

\footnotetext{
*原稿受付 昭和62年 5 月12日 昭和63年度春季全国大会で諭文発 表

**正 員 大阪工業大学 Member, Osaka Institute of Techology

***非会員大阪工業大学 Osaka Institute of Techology

****正 員 摄南大学 Member, Setsunan University

*****正 員 大阪府立大学 Member, University of Osaka Prefecture

******非 会員 京セう(株) Kyocera Co.
}

2）爆着プラグ部には，爆着による残留応力が存在し ていると考えられる.そこでオーステナイトステン レス鋼の爆着プラグ部では応力腐食㓶れ特性に関す る研究が必要である。

3）蒝気発生器が現在我が国で開発中の高速增殖炉に 使用される場合には爆着プラグ部の液体ナトリウム 中の腐食特性に関する研究が必要である ${ }^{3)}$.

上記の三つ環境強度に関する研究を行った結果をまとめ て報告する。

\section{2. 供試材料およひ試験片}

\section{1 プラグおよび管板素材}

供試材料は高速増殖炉の過熱器 $(\mathrm{SH})$, 蒸気発生器 (EV), および軽水炉の蒸気発生器 (SG) を想定し, SUS 321 ステンレス鋼, 21/4 Cr-1 Mo 鋼, SUS 304 ステ ンレス鋼を使用した。

化学成分, 機械的性實を Table 1 亿示す.

2.2 プラグおよび管板形状

Fig. 1 にプラグ断面形状を，Fig. 2 に模提管板形状を 示す.

\section{3 熱衙軹試験}

Table 2 に示す爆着采件により武験片を作製した。電 気雷管，爆薬およびプラグのセット状沉は，Fig. 3 に示 す通りである。

今回用いた方法は低爆速爆薬を使用した方法で，少量 の低爆速爆薬によるエネルギー不足を補い，管板端面近 
Table 1 Chemical compositions and mechanical properties of materials used (Mill sheet)

\begin{tabular}{|c|c|c|c|c|c|c|c|c|c|c|c|c|c|c|c|}
\hline \multirow[t]{2}{*}{ Materials } & \multicolumn{10}{|c|}{ Chemical compositions (wtr) } & \multicolumn{5}{|c|}{ Mechanical properties } \\
\hline & c & Si & Mn & $\mathbf{P}$ & $\mathbf{s}$ & Mi & $\mathrm{Cr}$ & Ho & cu & $\mathrm{Ti}$ & $\begin{array}{l}\text { Y.P. } \\
(M \mathrm{~Pa})\end{array}$ & T.S. & El. & $\begin{array}{l}\text { R.A. } \\
(\mathbf{x})\end{array}$ & $H_{B}$ \\
\hline $\begin{array}{l}\text { sus } 321 \\
\text { (Plug) }\end{array}$ & 0.04 & 0.69 & 0.76 & 0.631 & 0.004 & 9.13 & 17.26 & - & - & 0.4 & 225.4 & 588 & 56 & 73 & 163 \\
\hline $\begin{array}{l}\text { SUS } 321 \\
\text { (Tube plate) }\end{array}$ & 0.04 & 0.70 & 0.82 & 0.031 & 0.002 & 9.13 & 17.11 & - & - & 0.37 & 235.2 & 597.8 & 59 & 69 & 170 \\
\hline $\begin{array}{l}\text { SFVA F } 22 B \\
\text { (Plug) }\end{array}$ & 0.11 & 0.27 & 0.47 & 0.023 & 0.024 & 0.11 & 2.00 & 0.89 & 0.16 & - & 597.8 & 793.8 & 30 & 70 & 183. \\
\hline $\begin{array}{l}\text { SFva F } 228 \\
\text { (Tube plate) }\end{array}$ & 0.12 & 0.19 & 0.52 & 0.016 & 0.015 & 0.08 & 2.28 & 0.88 & 0.10 & - & 656.6 & 901.6 & 24 & 67 & 174 \\
\hline $\begin{array}{l}\text { sus } 304 \\
\text { (Plug) }\end{array}$ & 0.05 & 0.49 & 1.76 & 0.033 & 0.028 & 8.32 & 18.19 & - & - & - & 254.8 & 578.2 & 63 & 74 & 176 \\
\hline $\begin{array}{l}\text { SuS } 304 \\
\text { (Tube plate) }\end{array}$ & 0.05 & 0.31 & 1.02 & 0.034 & 0.024 & 8.08 & 18.17 & - & - & - & 225.4 & 817.4 & 64 & 73 & 179 \\
\hline
\end{tabular}

たので特別にクラッド鋼をつくりとのク ラッド鎆より試験片を採取した。.Fig. 4 に試験片の採取方法を, Fig. 5 に塩化マ グネシウム溶液を用いる応力腐食割れ試 験の形状を，Fig. 6 に高温高压水による 応力属食割れ試験の形状を示す.

2.5 液体ナトリウムによる席食試験 前節之同様に爆着プラグ部より試験片 を採取することができなかったので，ク ラッド鋼より採取した試験片の採取位置 を Fig. 7 に，武験片の寸法，形状を Fig. 8 に示す. Type A は爆着境界部を含む あの，Type B は母材部を代表するむの である．爆着プラグ部とクラッド鋼より 採取した試験片が大体同等の特性をあっ

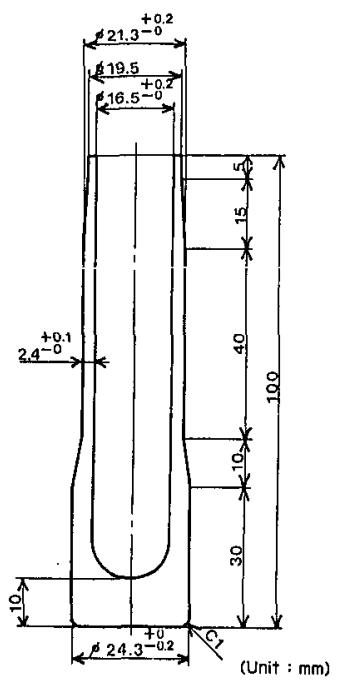

Fig. 1 Shape of plug

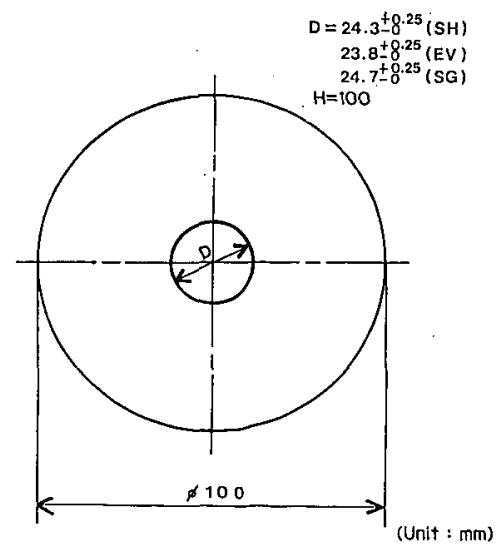

Fig. 2 Shape of tube plate

傍で爆速が上昇し，良好な爆着が得られるように逆起爆 法を採用した。

\section{4 応力屚食割れ試酫}

爆着プラグ部より武験片を採取することができなか。
Table 2 Explosive plugging conditions

\begin{tabular}{|c|c|c|c|c|c|}
\hline & Kind of exp. & $\begin{array}{l}\text { Height of exp. } \\
(\mathrm{g})\end{array}$ & $\left|\begin{array}{c}s / 0 \\
(\mathbf{c})\end{array}\right|$ & Plus thickness & Surface \\
\hline $\mathrm{SH}$ & L & 6.0 & 1.5 & 2.4 & 1320 \\
\hline EV & L & 5.0 & 1.4 & 2.5 & 1320 \\
\hline $\mathbf{s G}$ & L & 6.0 & 1.5 & 2.5 & 1320 \\
\hline
\end{tabular}

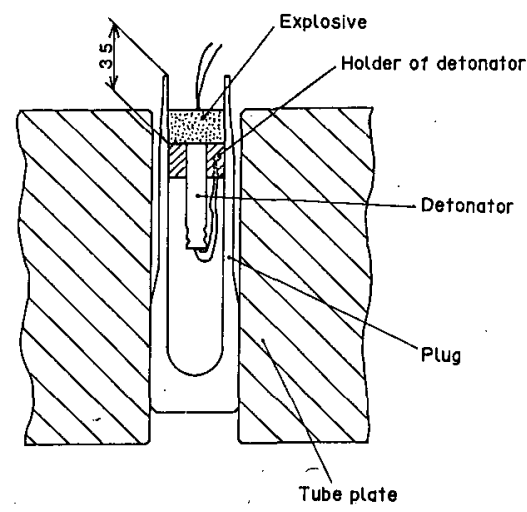

(Unit : mm)

Fig. 3 Setup of explosive plugging

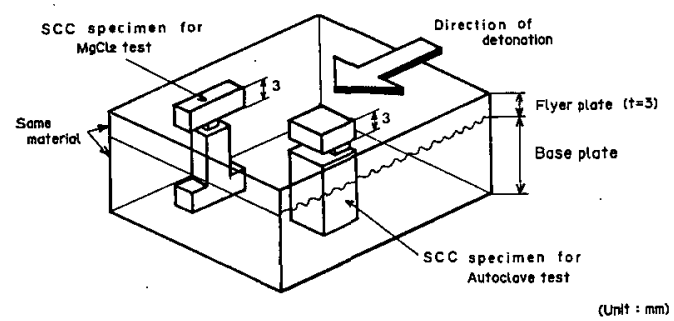

Fig. 4 Sampling of SCC test specimen for bonded boundary 

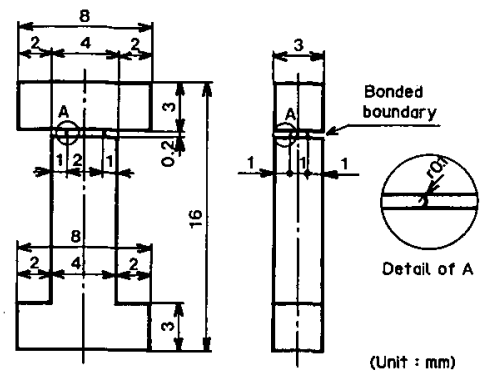

Fig. 5 SCC specimen for $\mathrm{MgCl}_{2}$ test

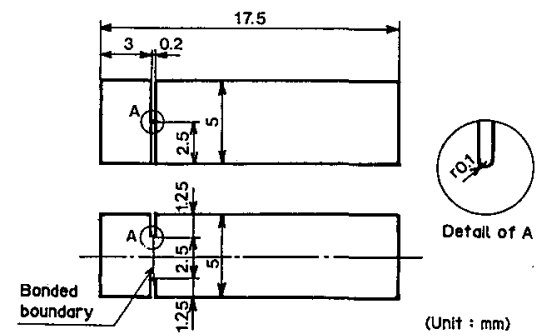

Fig. 6 SCG specimen for Autoclave test (Clad plate)

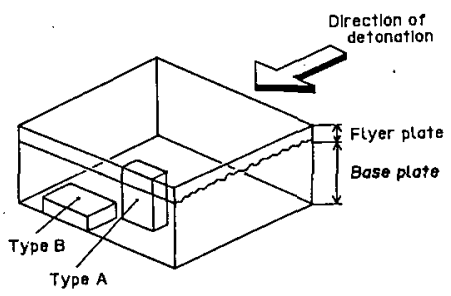

Fig. 7 Sampling of test specime for $\mathrm{Na}$ corrosion test

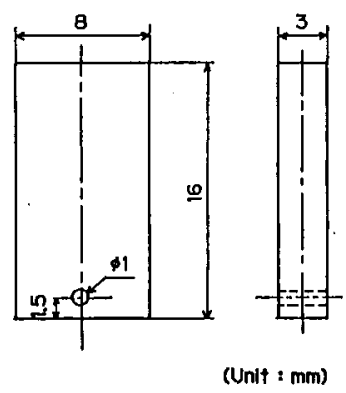

Fig. 8 Shape of test specimen for $\mathrm{Na}$ corrosion test

\section{3. 実 験 方 法}

\section{1 熟衡撃試駼}

\section{试験は次の手順で行った。}

i 熱衙撃試験前の超音波検查

ii 熱衝撃試験中の $\mathrm{AE}$ 波検出

iii 熱衝撃試験後の超音波検査

iv プラグ部の断面観察

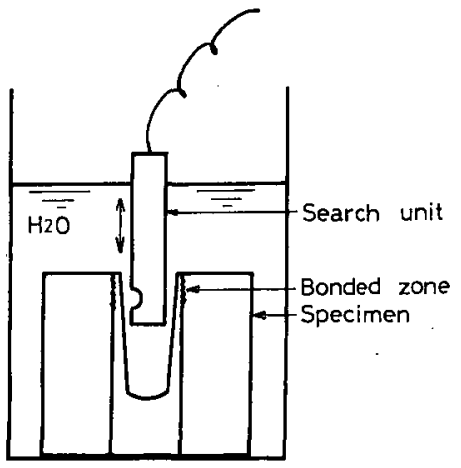

Fig. 9 Ultrasonic test (Full immersion mt method)

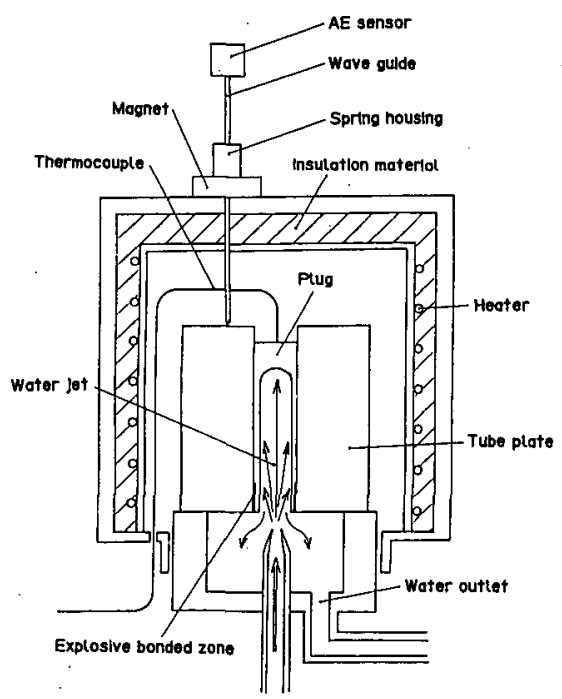

Fig. 10 Sectional plan of apparatus for thermal shock test

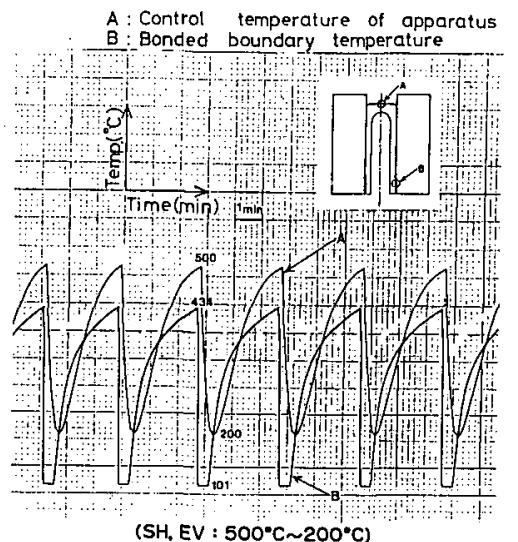

Fig. 11 An example of heating-cooling cycle

以下に簡笚に説明する。

（1）熱衙撃試験前後の超音波検查 
測定方法として Fig. 9 亿示すような水浸法を 採用した。探触子としては特製のペンシル型の ものを用いた。

\section{(2) 熱衝撃試験}

本試験に用いた試験装置の概略を Fig. 10 に示 す．この装置では，ヒーターにより陚験片を加熱 し, 武験片温度が上帠に達するとノズルからの水 噴射により冷却が開始され，試験片温度が下限に 達すると水噴射が停此し，冷却を終了，再び試験 片が加熱される上うになっている。爆着部におけ る冷却速度は $50 \sim 100^{\circ} \mathrm{C} / \mathrm{sec}$ である。 Fig. $11 \mathrm{~K}$ 嫣験片の加熱一冷却サイクルの一例を示す。

さて高速增列炬「むんじ心」の場合，熟衝撃の 想䈝事象としては Table 3゙のようなものがあ る. 本研究では, Fig.12 のような「もんじゅ」 の蒸気発生器各部の温度加ら考え, 熱衝撃試駼温 度条件を Table 4 のように定めた。熱衝撃試験中の割れ や，はく離の発生時期を明確に探知するためアコーステ ィックエミッションの測定を行った. Fig. 13 に AE 検

Table 3 Supposing occasion of thermal shock test

\begin{tabular}{|c|c|c|}
\hline Supposing occasion & Cooling rate ( $\mathrm{C} / \mathrm{sec})$ & Temperature range (C) \\
\hline $\begin{array}{l}\text { * "Yonju" EV } \\
\text { * Feed-water side } \\
\text { entrance nozzle } \\
\text { cold shock } \\
\text { * Misoperation wain } \\
\text { steas duap val ve } \\
\text { "Open" }\end{array}$ & 1.5 & $240 \sim 156$ \\
\hline $\begin{array}{l}\text { * "Monju" EV } \\
\text { * Stean side exit } \\
\text { nozzle hot shock } \\
\text { \& Feed-water discharge } \\
\text { regulating valve } \\
\text { "Close" }\end{array}$ & 0.5 & $90-83$ \\
\hline
\end{tabular}

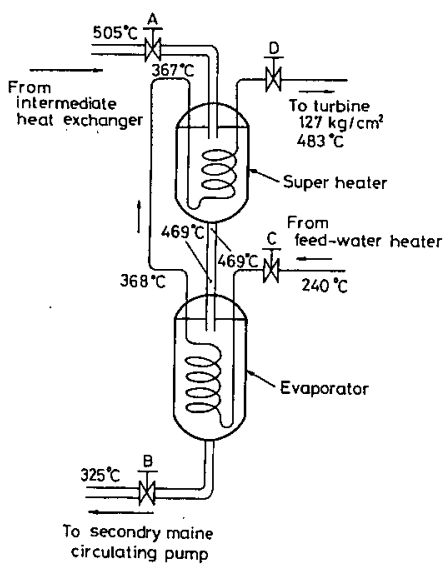

Fig. 12 System drawing of steam generator (Monju)

Table 4 Temperature conditions for thermal shock test

\begin{tabular}{|c|c|c|}
\hline & Max.temp.(C) & Min.teap.(C) \\
\hline S H & 500 & 200 \\
\hline E V & 500 & 200 \\
\hline S G & 300 & 100 \\
\hline
\end{tabular}

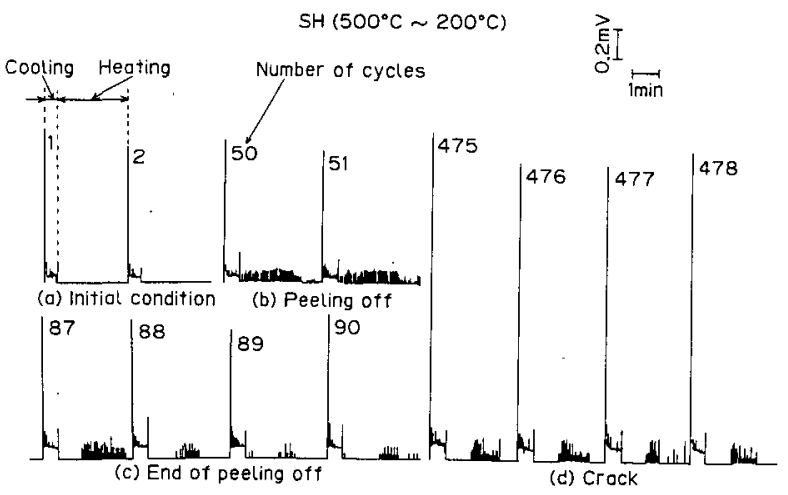

Fig. 13 AE behavior during thermal shock test (R.M.S.)

波の一例を示す. Peeling off の発生, 䅂了, Cracking 之AE との対応については，武験中においてそれそれれの $\mathrm{AE}$ の発生直後に装着を停止し, 試験片をとりはずして 試験片を切断し，断面を観祭することによって決めた，

\section{2 応力席食割れ試験}

$\mathrm{MgCl}_{2}$ 溶液による実験としては,供武材料として SUS 304 銿うみを使用した。乙れを $42 \% \mathrm{MgCl}_{2}$ 胇滕溶液中 に浸漬して引張一定荷重を加え破断までの時間を測定し た.また実際の軽水炬の環境を模擬した試験として高温 高压水による応力腐食割れ武験を行った，実験方法とし ては，Fig. 6 の試験片を曲げ冶具にとりつけ曲げ荷重を 加えたまま，静止型オートクレープに蒸留水とともに封 入した。高温水は温度 $250^{\circ} \mathrm{C} \pm 5^{\circ} \mathrm{C}$, 圧力 $42.6 \mathrm{~kg} / \mathrm{mm}^{2}$ とし，水中溶存酸素濃度を $100 \mathrm{ppm}$ とした。 また 100 时 間ごとに蒸留水の交換および酸素の注入を行い, 実験終 了後切欠先端部を切り出し，割れの有無を観察した。

\section{3 泝体ナトリウムによる席食試験}

液体ナトリウムによる腐食試験を行うためには, 高速 増殖炉の二次ナトリウム系の環境条件を忠実に再現した 「ナトリゥムループ装置5」を用いるととが望ましいが， 本研究ではいくつかの奏際的な制約により, 比較的簡単 で小型の「ナトリウムループ」を試作して研究を行うこ ととした．このような関係より研究の目的も，爆着部之 母材部の腐食抵抗を定性的に比較することにとどめた，

Fig. 14 に試作した「ナトリウムループ」のフローシ ートを示す、図中，TT は陚験片を涭清するテストタン クであり，CT は液体ナトリウムを融点直上まで令却し てナトリウム中の酸化物を析出させて捕集し，溶存酸菜 量を制御するためのコールドトラップである，その他， EMP はナトリウムを流動させるための電磁ポンプ, EMF は電磁流量計，VTはナトリウム蒸気を捕集する ためのベーバートラップである。なお採用した試倹条件 は次のようである。

$\begin{array}{ll}\text { 温度 } \quad 600^{\circ} \mathrm{C}, 700^{\circ} \mathrm{C} \text { 酸素濃度 } \quad 1 \sim 2 \mathrm{ppm} \\ \text { 流速 } & 2.5 \mathrm{~cm} / \mathrm{sec}\end{array}$

\section{4. 実 験 結 果}

\section{1 熱街整試験}

実験結果を Fig. 15 に示す。試験結果は横軸にサイク ル数 (注水回数) をとり, 縌軸にプラグ部の温度変化の 範囲を示して整理した。 はく離は武験開始直後から起き ていると思われるが，刍裂の発生までにはある程度時閣 


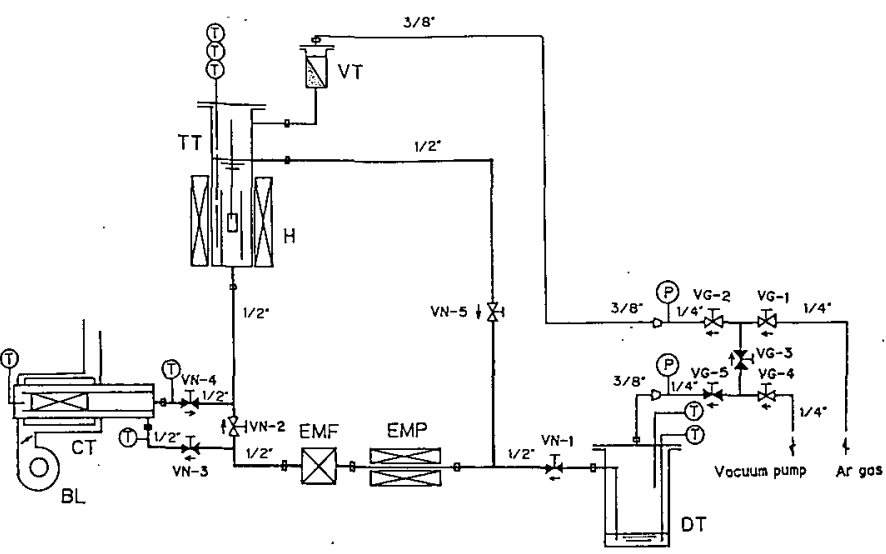

Fig. 14 Flow sheet of $\mathrm{Na}$ loop
$\mathrm{MgCl}_{2}$ 溶液中の定荷重引张試験にお ける試験結果を Fig. 16 に示す。また高 温高压水による応力歷食㓶れ試験の結果 を Fig. 17 亿示す.

Fig. 16 加ら母材部よりも爆着境界部 の方が応力腐食制れ感受性が低いことが わかる。 また Fig. 17 より高温高圧水中 での試験では，乙の場合応力腐食割れは 発生していないととがわかった。

4.3 液体ナトリゥムによる度食試験 液体ナトリウムによる腐食試験の結果 を Fig. 18, Fig. 19 に示す.乙れらの結 果では程軸に試験片の単位表面積当たり の府食減量を示している，Fig. 18 より 爆着境界部を拿む Type A 試験片は，母: 材を代表する Type B 試験片よりすわず かながら鹰食減量が大きい傾句にあるこ
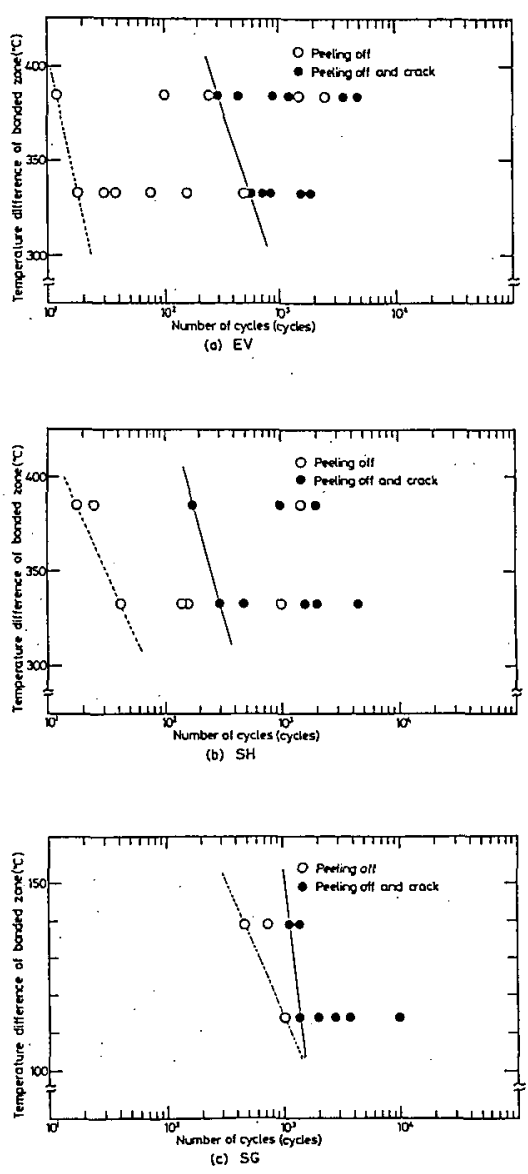

Fig. 15 Results of thermal shock test

を要しまたこの龟裂がブラグ内側もしくは，管板外側 まで伝播するためにはかなりのサイクル数が必要と思わ れる。 また熱衝撃試験終了後，藏験片を切断して破壊の 模様を観察した，観察結果の概略については，5.1で述 べる.

\section{2 店力底食割れ試験}

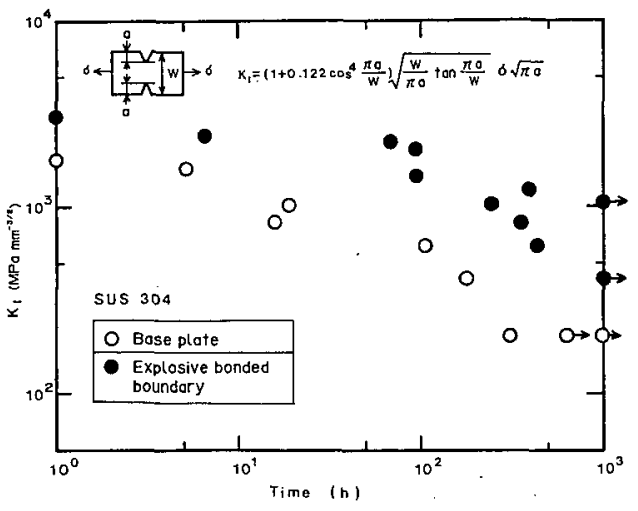

Fig. 16 Result of $\mathrm{MgCl}_{2}$ test

とがわかる．また Fig. 19 より $700^{\circ} \mathrm{C}$ におりる腐食減量 はこれら二つの材料においては $600^{\circ} \mathrm{C}$ における腐食減量 にくらべ非常に大きくなるととがわかる．「あんじ心」 の二次ナトリウム系の温度は Fig. 12 より $500^{\circ} \mathrm{C}$ 程度と 考えるとこれらの試験温度は現実の場合より高く加速試 験的な条件であることがわかる。

\section{5. 考察}

\section{1 熱衡望試験}

Peeling off の発生, Cracking の時期は，材質と試験 条件の両者によって異なると思われる。例えば Fig. 15 の(C)の場合 Peeling off の発生時期が他の場合より遅い のは，熱衝撃の温度差が他の場合より小さいととが関係 していると思わ㞦る。

爆着プラク部の熱衝撃におりるはく離および亀裂発生 のメカニズムとしては Fig. 20 に示す三つの型があると 若えられる．1 は爆着の始端部で爆速の立ち上がりが不 允分なために起因する接着不良部がはく離し，この部分 より龟裂がおこる場合，2は爆着の終端部の非压着部上 り龟裂がおこる場合，3は压着境界部に出来た溶融部か ら，熱衝撃により，放射状に繁加発生し炊第に境界線 に渓って進行して行く場合である。

\section{2 応力摩食割れ試験}

爆着プラグ後の模擬管板端面の残留応力分布を歪解放 

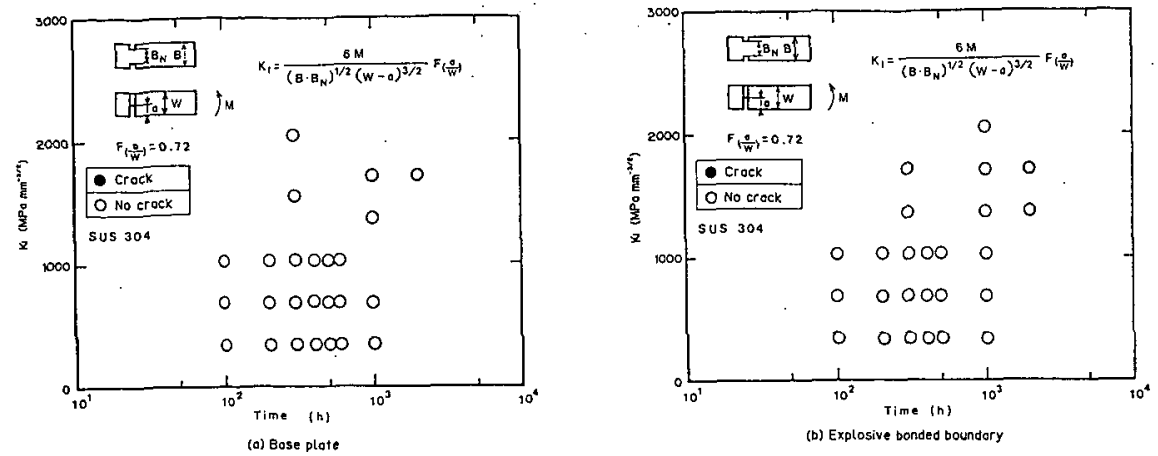

Fig. 17 Results of Autoclave test

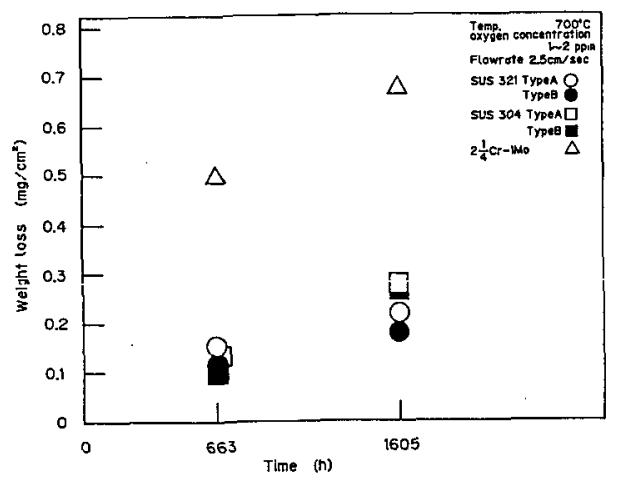

Fig. 18 Weight loss vs. time in Na corrosion test

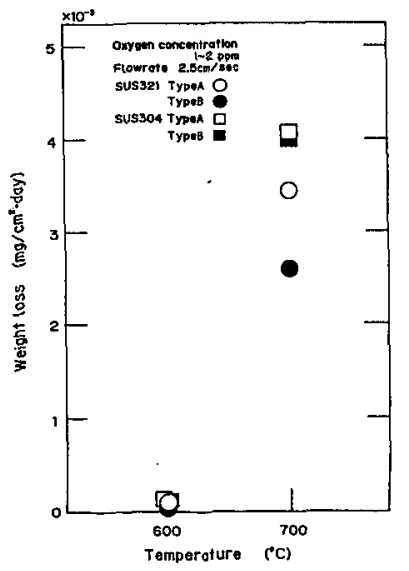

Fig. 19 Weight loss vs. temperature in $\mathrm{Na}$ corrosion test

法により測定してみると Fig. 21 のようになる，当然の ことであるが半烽方向および円周方向の応力はプラグ近 傍では王縮であり，乙の部分に応力腐食割れは発生しな い.一方試験片全体を $\mathrm{MgCl}_{2}$ 溶液に浸漬してみると Fig. 22 に示すように割れが発生した。爆着による残留 引張応力は，プラグの軸方向に作用していたものと思わ れる。

Fig.16にみられるように $\mathrm{MgCl}_{2}$ 溶液による応打腐食

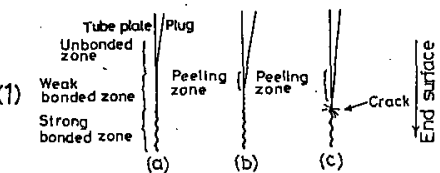

(2)

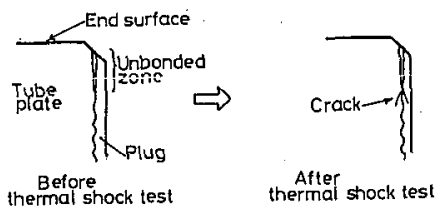

(3)

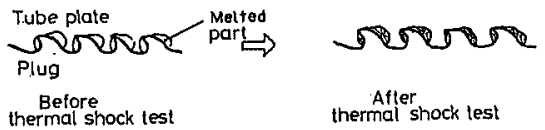

Fig. 20 Mechanisms of peeling off and crack
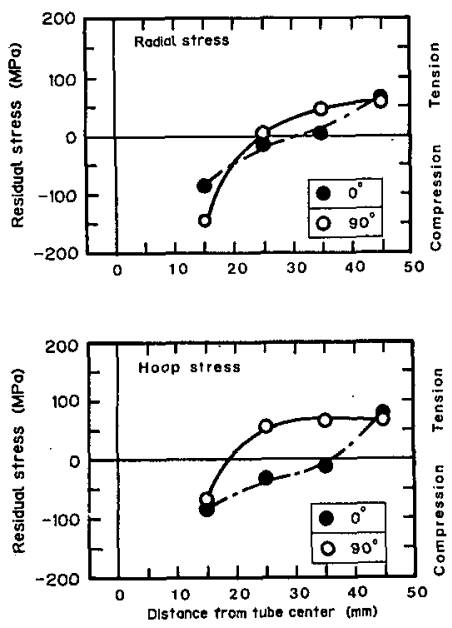

Fig. 21 Residual stress distribution in tube plate for SUS 304 explesive plugged tube

割れ試験の結果，爆接材は母材に比較して応力符食割れ 感受性は低いといえる。乙れは主として爆着によって生 じた加工請起マルテンサイトに関係するすのと思われ る6,7)。また Fig. 17 によれば高温高圧水による応力腐食 


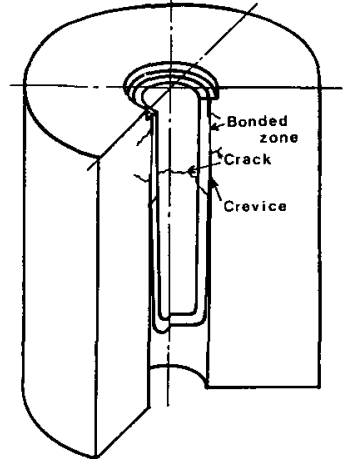

Fig. 22 General view of specimen after corrosion test $(3000 \mathrm{~h})$

制れ式験では母材，爆着材とも割れの発生は認められな かったが，乙れは爆着の割合，熱の発生が非常に少なく 村料が銳敏化されないためと思われる。

\section{3 液体ナトリゥムによる度食試験}

Fig. 18 亿おいて爆着材は母村よりわずかながら腐食 娍量の多いことが認められたが，このととはナトリウム 腐食の機構8) より考えると次の上うに解橎できる。ナ リウムによる腐食の場合， $\mathrm{Ni} ， \mathrm{Mn}$ などは液体ナトリウ ム中に直接溶解するが， $\mathrm{Fe} ， \mathrm{Cr}$ などは介在する微量の 酸素ならびにナトリウムによる三成分酸化物の生成, 溶 解によって減少するといわれている，爆着境界部では母 材部よりあ酸化物が多く，てれより生じる酸素が腐食を 促進させるのではないかと考えられる。

\section{6. 結 論}

(1) 爆着プラグ部の熱㣫撃試験を行ったところ，はく 離はくり返し陚験開始值後加ら生じるが，とのはく 離加ら亀裂が発生するには相当のくり这し数を要 す，魚裂発生のくり返し回数は，高速增殖炉の過熱 器で 150 200 cycle, 高速增殖炉の蒸発器で 200 400 cycle, 軽水炣の蒸気発生器では 1000 cycle 价 である。

(2) $\mathrm{MgCl}_{2}$ 溶液による応力腐食割れ感受性は母材よ
り无爆着材の方が低い。

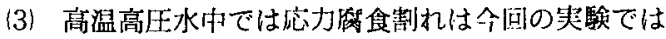
認められなかった。

(4)液体ナトリウムによる腐食試験では，爆着部のう が母村部よりもわずかながら腐食诚量が大きいよう である.

\section{謝 辞}

本研究を遂行するに当たり，研究に対する多くの討 論，アドバイスをいただいた大阪工業大学機械工学科， 井川博教授に深甚の謝意を表したい。また応力腐食割 れ武験について愁切な討論をいただいた大阪大学向井喑 彦教授および「ナトリウムルーブ装置」の試作に関し， 熱心なご指導をいただいた鉝風材料技術研究所鈴木正室 長にも心からのお礼を申し上げる。

さらに大阪工業大学大学院において本研究の実行に当 たった佐久間宏輔君（グイセル化学），日羙正治君（立 石電機)，森本裕介君（川崎重工）に感謝する。最後に 本研究は文部省科学研究費 (一般研究B) によるもので あることを付記する。

\section{参考 献}

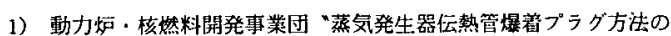
開発“ PNC SN 941 80-170 (1980)

2）日本溶接協会、“蒸気発生器伝熱管プラグ式の開発 (V)", EPE 委員会成果報告書, PNC SJ 225 82-01 (1982)

3）加賀精一，藤井克弘，藤岡芳博，山本義秋，小川佰一・小型ナ卜 リウムループの試作と爆着プラグ部のナトリウム䋀食に関する研 究”溶接学会論文集，第 5 巻，第 3 号

4） IHI “爆着プラグ部の熱衝撃試験”日本溶接協会爆著プラグ部の 評洒委員会疽料 (1982)

5）鈴木正他 “材料試験用ナトリウムループの試作”科学技術庁金属 材料技術研究所研究報告集 4,P.324 P.334 (1983).

6）村田雅人，向井喜彦“種々の環境下们ける SUS 304 鎆の灾力 腐食割狆の力学的分類“ 日本金属学会誌，第44巻，第 3 号。(1980) P. $230 \sim P .238$

7) M. WATANABE and Y. MUKAI "Effect of Cold Working on Stress Corrosion Cracking of Austenitic Stainless Steel and Their Welded Joints". Technology Reports of the Osaka University, Vol.20, No.917, (1970) P.99 p.120

8）鈴木正，野田哲二“液体了ルカリ金属中の金属材料の䋀食 (I)" : 防食技街，24 (1975)，593. 他 